\title{
Professional development of elementary school teachers at the beginning of their careers: the role of project-based learning
}

\section{Desenvolvimento profissional de professores do ensino básico em início de carreira: o papel da metodologia de trabalho de projeto}

\section{Desarrollo profesional de profesores principiantes de educación básica: el papel de la metodología de trabajo por proyectos}

\author{
Tiago Tempera ${ }^{1}$ iD Luís Tinoca $^{1}$ iD \\ ${ }^{1}$ Institute of Education, University of Lisbon, Lisbon, Portugal. \\ Corresponding author: \\ Tiago Tempera \\ Email: tiagot@eselx.ipl.pt \\ How to cite: Tempera, T., \& Tinoca, L. (2022). Professional development of elementary school teachers at the \\ beginning of their careers: the role of project-based learning. Revista Tempos e Espaços em Educação, 15(34), e16945. \\ http://dx.doi.org/10.20952/revtee.v15i34.16945
}

\begin{abstract}
The beginning of a teacher's career is a challenging period for the development of their educational practices, being essential for their professional development. This study aims to understand the role of Project-based learning in the professional development of elementary school teachers at the beginning of their careers. The qualitative analysis carried out is based on the data collected through semi-structured interviews to eight beginning teachers. Results show that beginning teachers show some difficulties in integrating these methods in their teaching practices, which could be lightened through a more consistent collaboration between initial teacher education institutions and schools, in order to facilitate their career integration and professional development.
\end{abstract}

Keywords: Beginning teachers. Induction phase. Learner-centred education. Professional development. Project-based learning.

\section{RESUMO}

O início da carreira docente é um período desafiador para o desenvolvimento das práticas educativas de um professor, sendo fundamental para o seu desenvolvimento profissional. Este estudo tem como objetivo compreender o papel da Metodologia de trabalho de projeto no desenvolvimento profissional de professores do ensino básico em início de carreira. A análise qualitativa realizada é baseada nos dados recolhidos através de entrevistas semiestruturadas a oito professores iniciantes. Os resultados mostram que os professores iniciantes apresentam algumas dificuldades em integrar este método nas suas práticas de ensino, o que poderia ser atenuado através de uma colaboração mais consistente entre as instituições de formação inicial de 
professores e as escolas, a fim de facilitar a sua integração na carreira docente e o seu desenvolvimento profissional.

Palavras-chave: Desenvolvimento profissional. Ensino centrado no aluno. Fase de indução. Metodologia de trabalho de projeto. Professores iniciantes.

\section{RESUMEN}

El inicio de la carrera docente es un período desafiante para el desarrollo de las prácticas educativas del profesor, siendo fundamental para su desarrollo profesional. Este estudio tiene como objetivo comprender el papel de la metodología de trabajo por proyectos en el desarrollo profesional de los profesores de educación básica al inicio de sus carreras. El análisis cualitativo realizado se basa en datos recopilados a través de entrevistas semiestructuradas con ocho profesores principiantes. Los resultados muestran que los profesores principiantes tienen algunas dificultades para integrar este método en sus prácticas docentes, lo que podría mitigarse mediante una colaboración más consistente entre las instituciones de formación inicial del profesorado y las escuelas, con el fin de facilitar su integración en la carrera docente y su desarrollo profesional.

Palabras clave: Desarrollo profesional. Enseñanza centrada en el alumno. Fase de inducción. Metodología de trabajo por proyectos. Profesores principiantes.

\section{INTRODUCTION}

Teachers' learning process does not end with Initial Teacher Education (ITE), it starts with it. In this stage, future teachers come into contact with diversified teaching methods, such as Projectbased learning $(\mathrm{PjBL})$, which generally contrast with the type of teaching methods, centred essentially on the teacher, that they experienced throughout their school paths. Considering that professional development (PD) occurs when there are changes in knowledge and conceptions about teaching and in what it means to be a teacher, ITE is the beginning of teachers' PD path.

Along their professional path, teachers go through a process of personal and professional growth that is not limited to the knowledge and skills related to teaching practice acquired in ITE. In this sense, teachers' PD is a constant and continuous process that contributes to the improvement of their practices, with the ultimate goal of preparing students for handling the complexity of modern societies (Haug \& Mork, 2021).

One aspect that limits teachers' PD is related to the difficulty in integrating the educational systems during the first years of service. Tickle (2000) mentions several case studies that refer to a state of uncertainty and anxiety in the induction period of a teacher's career, since the expectations, when starting the new profession, contrast with the encountered reality regarding colleagues, members of the school management bodies and working conditions. In terms of research, although it is increasing, there are still few studies focusing on beginning teachers, as stated by Príncepe and André (2019) in their literature review on the teacher education area.

Regarding teaching evolution of the elementary school levels in Portugal (1st to 4th grade) in recent years, the central core of the curriculum has remained stable, but the same cannot be said about the evolution of pedagogical theories and didactical processes (Leite, 2018) that try to keep up with the demands for the 21st century. Thus, the elementary school teachers' PD involves the development of professional skills related, among others, with the ability to make the content meaningful, interconnecting it within various areas of knowledge.

One of the active teaching methods that allows knowledge and content interconnection from various curricular areas is PjBL. Many teachers have resorted to using this method in their educational practices to better prepare students to become active citizens for the 21st century (Condliffe et al., 2017). However, despite valuing active and collaborative learning methods, many teachers find it difficult to implement this type of work with their students (Diesel \& Matos, 2019). Research wise, Choi et al. (2019) refer to some studies that focus on how PjBL can be applied by 
future teachers in ITE, but not many addresses how teachers integrate this method in their educational practices.

It is in ITE that future teachers begin to develop their professional skills, but it is in the induction phase that the greatest transformations occur, influenced by the experiences arising during their career integration (Flores \& Day, 2006). In this sense, this PD phase constitutes an essential moment for the use of active teaching methods, such as $\mathrm{PjBL}$, since it is this stage that teachers shape their understanding of teaching processes and reconstruct their professional identity.

Prior to the present research, a study was carried out with higher education institutions in which the participants attended during their ITE (Tempera \& Tinoca, 2020). The results revealed that the institutions make an effort to integrate $\mathrm{PjBL}$ during their programs in theoretical, didactical or practical terms as some courses' working methods. However, they find it difficult to promote more meaningful experiences to students so that they could feel more confident in using this method in their practicum.

With this research we aim to understand the role of PjBL in the PD of elementary school teachers at the beginning of their careers. The research questions that guide this project and which we address in this paper are: 'What is the level of preparation felt by elementary school teachers for the development of projects with students?'; 'What is the role of PjBL in the development of teacher professionality conceptions?'; 'How is the induction phase of beginning elementary school teachers characterized?'; and 'What aspects facilitate and/or hinder teachers' PD at the beginning of their careers?'.

\section{Project-based learning}

PjBL can be considered as an active group learning method that presupposes the involvement of all participants, in order to solve real-life problems in the pupils' common interest, in which they learn to seek solutions for questions they pose, by having a brainstorm of ideas, establishing a plan, researching and communicating with others (Choi et al., 2019). The entire process allows the development of essential lifelong learning competences, such as the spirit of initiative and creativity, social learning in group work and decision-making.

In this sense, T. Leite and Arez (2011) defend the inclusion of project work practices in ITE, allowing future teachers to acquire intervention and curriculum integration competences. Despite not being a recent method, Choi et al. (2019) reinforces the idea that PjBL remains effective and meaningful, as an active learning method for children and a means to improve teacher self-efficacy.

Reinforcing the positive aspects of PjBL implementation in classrooms, Revelle (2019) states that teachers acquire a different view of the curriculum and an improved perception on this method's viability. She also mentions several studies that explore teachers' perceptions about the obstacles in the implementation of PjBL, identifying the time necessary to prepare and develop projects, their adaptation in changing defined roles in the classroom from a more transmissive model to one focused on the student, classroom management, the concern about not covering the whole curriculum when spending time on project work and the difficulty in supporting students' learning diversity.

Tamim and Grant (2013) add other challenges to the implementation of PjBL, that teachers need to take into account when using this method in their teaching practices. For these authors, teachers need to be open to constructivist approaches, to develop learner-centred teaching skills, to have motivation and the ability to adapt their teaching strategies and to develop self-confidence to manage activities resulting from project work. Believing in the effectiveness of PjBL as a constructivist model of learner-centred education becomes essential for teachers, so that they feel able to overcome the difficulties of its implementation. Consequently, teachers' PD can have these beliefs as a basis, contributing to the extension of this method's application in classrooms. 


\section{Elementary school teachers' professional development}

PD can be seen as a long-term process experienced by teachers in interaction with the school environment, through formal and informal experiences, with the goal of improving their educational practices and promoting educational changes that benefit the school community (OECD, 2011). Several authors (Ilaiyan \& Safadi, 2016; Oliveira-Formosinho, 2009; Vonk, 1995) consider PD to have a complementarity between three different dimensions: (i) a personal understanding dimension, centred on teachers themselves and their individual growth, which encompasses knowledge about oneself and one's own ideas about good teaching practices; (ii) a knowledge and skills dimension, related to the processes of acquiring scientific and pedagogical knowledge and organizational competences for the teaching-learning process; and (iii) an ecological dimension, which corresponds to the teachers' introduction period and adaptation to the school environment and their capacity for integration, as agents of changes.

Despite the importance of ITE for teachers' PD, Gatti and Nunes (2009) also recognize its most pressing problems, such as knowledge fragmentation and the weak link between theory and practice, which make it difficult to resolve teaching practices related issues. Supporting these ideas, Mielkov et al. (2021) state that ITE should help students to develop critical thinking and to create their own knowledge, establishing a transition from a transmissive type of learning to a studentcentred one.

Bearing in mind that the elementary school is a stage of basic education distinct from other teaching levels, due to its own characteristics at a curricular, pedagogical and didactical levels (Leite, 2018), being a teacher at this level of education also has its own way of PD. Despite the stability in the evolution of the elementary school curriculum, it has been verified, in recent years, an evolution about the knowledge of what is taught and how it should be taught. In addition to these aspects, there is a difficulty on collaborative work between teachers from the same institution, especially in the first years of teaching, which can lead to a return to a more traditionalist transmissive practices, resembling the practices of older colleagues (Tickle, 2000).

Considering PD as a lifelong learning experience, Bezzina (2006) suggests a stronger connection between ITE, the induction period and the PD in order to create a more coherent development and learning system. In this sense, Onyshkiv et al. (2021) also encourage a closer contact between higher education institutions and schools, in order to introduce different types of pedagogical practices.

The implementation of the University Schools innovative concept in several countries has significantly narrowed the gap between ITE institutions and schools and the relationship between theory and practice. The intention of University Schools is to create strategic partnerships between universities and schools, in order to promote the training of future teachers and, at the same time, cooperate in research and school development processes (Gerholz et al., 2020). To Smith (2016), this concept allows working very closely to the field of practice, being a way to reduce curricular fragmentation, experienced by future teachers in ITE, by integrating the educational components, didactical knowledge and pedagogical skills. Schools also benefit from this proximity, developing themselves through teaching innovative methods, implemented by future teachers and providing contextualized fields for research.

\section{Teachers' induction}

The teaching career induction period establishes the transition from students to teachers. Some authors consider the first year of service to be the teacher's induction period (Tickle, 2000). Príncepe and André (2019) disagree with this established period of time, stating that, until teachers do not attain professional stability, they will continue to experience situations of exploitation, struggle for survival and adaptation to new contexts, which are typical characteristics of the 
induction phase. Making an analogy between childhood and the induction phase, as the quality of what is lived in the first years determines its own development for adult life, the authors reinforce that the induction phase must take into account teachers' work conditions and not be defined by a determined period of time.

Considering the profession's first years as extremely demanding, Harju and Niemi (2016) refer that ITE, although providing bases for teachers' work, does not prepare beginning teachers for their professional life. In their study about beginning teachers' needs for PD in Finland, the United Kingdom, Portugal and Belgium, these authors reinforce their need for support in resolving conflicting situations and in differentiating teaching methods within a classroom. In the specific case of Portuguese teachers, they reveal a greater need for support in carrying out research about their own practices, since they consider themselves as active researchers and innovation agents in their own work.

Tickle (2000) mentions several factors that increase these problems, namely the school culture and policy, the isolated nature of teaching practices that doesn't encourage collaborative work between teachers, the demanding tasks to be performed, the lack of time to meet with colleagues to discuss pedagogical aspects and the expectation that beginning teachers will follow the advice and methods of the most experienced ones.

Bezzina (2006) also mentions beginning teachers' difficulties, referring to aspects such as the anxieties and tensions on the first classes they teach, the difficulties in managing complicated classroom situations by having mixed-ability groups, or the lack of institutional strategies for teachers' integration.

The OECD (2011) suggests that schools could offer well-structured induction programs to beginning teachers and could reduce the priority given to seniority, in order to balance the amount of work and not overload beginning teachers with overly demanding tasks. It also recommends that ITE provide postgraduate programs that prepare teachers to integrate different types of schools and different grades, increasing their opportunities to be placed in schools with different methods. To that end, ITE institutions must maintain a close connection with schools and with the teaching profession itself, in order to respond to beginning teachers' needs. Creating a school mentor, that provides guidance and supervision to beginning teachers, may be an important element in this integration, especially if there is coordinated work with ITE institutions, which would be able to monitor the process, ensuring the quality of the mentorship process. In order to develop teachers' professional competences, Rudkevych et al. (2020) also support the active use of mentoring. However promising, Spooner-Lane (2016) states that the impact of mentoring on teaching practices remains unclear, due to the lack of research on this subject.

In spite of the experienced intensity in the first years of their careers, Harju and Niemi (2016) consider that this factor does not mean that beginning teachers are not capable or competent in their work. In this sense, the emphasis on PD should not focus on incorporating new teachers into existing cultures, but supporting them in promoting school culture development.

\section{METHODOLOGY}

This research is situated in a phenomenological-interpretative paradigm (Cohen et al., 2018) seeking to understand the subjectivity of human experience and, at the same time, to maintain the integrity of the investigated phenomenon and to interpret it from the participants' point of view. Thus, the inferences made emerge from the particular observed situations. There is a concern to understand and interpret the observed situations taking into account its participants.

The participants of this study are eight elementary school teachers in the induction period, having between 2 and 5 years of professional experience at this school level and using PjBL in their educational practices. Teachers were selected through the indication of the coordinators of their ITE programs, from two higher education institutions with similar teacher education models, but 
with different curricula. Both institutions contemplate project work as an inherent method to its programs. The criteria for selecting teachers took into account the years of teaching service (no more than five) and the fact that they use or have used PjBL in their educational practices on elementary school levels.

Data collection was carried out through semi-structured interviews with each of the participants, in order to understand their perspectives on the role of PjBL in their PD. The interviews were based on a previously defined protocol, ensuring that all the participants would answer the same questions, while maintaining a degree of freedom in its exploration, trying not to separate facts from the context in which they occur (Mason, 2017). The questions were prepared in order to collect data about the level of preparation felt by the participants for the development of projects with their students, the role of PjBL in the development of the participants' professionality conceptions, the main characteristics of the participants' induction period, and the aspects that facilitate or hinder the participants' PD. Due to the pandemic situation and mandatory confinement in which the country was subject to during the research, all interviews were conducted online, via videoconferencing platforms.

Subsequent to the interviews, the collected data was subject to content analysis (Amado, 2017) and categorized according to the observed regularities and identified common aspects, according to the research's objectives. The identified topics through the obtained results emerged from these categories. The teachers' names are fictitious, maintaining the anonymity of the participants and data confidentiality.

\section{RESULTS}

Throughout the conducted interviews, 10 topics emerged demonstrating the role of PjBL in the PD of elementary school teachers at the beginning of their careers. These topics are related to the research questions, which will be the focus of the presentation and discussion of the obtained results.

Research question 1: "What is the level of preparation felt by elementary school teachers for the development of projects with students?"

All the participants of this research had contact with PjBL during ITE, either in practical terms, as a course's work method, or in theoretical and didactical terms. For six teachers, it was the first contact they had with this method. The remaining two had the opportunity to carry out projects during their school paths, in an extinct subject called Project Area, which they recognize as not being very impactful, as it was simplistic in its design and resembled common group work, similar to the ones they did in other subjects. Seeking to understand their perception of the preparation provided by ITE for project work with pupils, two topics emerged. Teachers recognize that the preparation for this type of method was insufficient, but also that the possibility of applying PjBL in their practicum was decisive for their preparation.

\section{Topic 1: insufficient experience with PjBL}

Seven of the eight teachers consider that they did not feel fully prepared to develop project work with their pupils, after completing ITE. The reasons expressed are related to the lack of practical experience during the program, the lack of connection between theory and practice, the little depth of the approach in the courses, and the impossibility of applying this method in their practicum, due to the school context's circumstances or the methods adopted by the class's head teacher at the host school (called Cooperative Teacher).

The lack of practical experiences during ITE was mentioned by the teachers as a reason for their insufficient preparation. The theoretical approach was not considered sufficient, so some participants would have liked to have experienced this method in some program's courses, such as 
Hélia who states that "in [name of the institution where the ITE was carried] we have never done such work, with this specific method". Elisa refers to her experience in ITE as not being very rich in methodological terms. In her opinion:

Sometimes, in teaching training, there is a bit of fear of embarking on or introducing student teachers to these methods that uninstall us ... There is a certain fear of putting us through these methods ... Because, imagine, if I am a professor and I don't believe in the method, maybe I will not present it my students.

Some participants report that there is little connection between theory and practice, as they feel that some ITE professors do not have a direct link with elementary school teaching practices, and present theory disconnected from reality. Diana justifies that:

Theory is often nothing like that. In [name of the institution where the ITE was carried] they could tell us the world, but when we get to the field of practice, sometimes it is not possible to do anything like that... many other things happen in a school.

The lack of depth in the method's approach was another of the reasons pointed out. Some participants report that PjBL's approach was superficial, taught at the same time as other methods, without having enough time to internalize it. Ivo reports that "during the undergraduate program we talked a little about it, very lightly. In the master degree we talked more. But ITE was insufficient". Hélia shares the same opinion, referring that ITE gave her bases, but did not adequately prepare her for the type of work that she faced when she started her career.

In spite of the aspects mentioned, most participants admit the importance of ITE for their professional preparation. Glória says: "I think we only can improve when we are in the field. But everything we learned was important ... what we learned in theory and then seeing it put to work in practice, was an asset". In an effort to fill some gaps pointed out in ITE and in order to feel more prepared, some teachers suggest that ITE should promote moments of practice, according to this method, in courses from different areas of knowledge offering the possibility of applying this method in the practicum, and to promote more contact with the school reality by inviting elementary school teachers to talk about their real-life experiences.

Only Filipa considers that she felt confident in applying PjBL with her pupils, after ITE, referring "I felt completely prepared... This is because of all the internships I had being very rich. It was an excellent experience... I consider that my training was quite significant regarding this method". Furthermore, Filipa recognizes the importance and contribution of the practicum for this purpose, which leads us to the second topic of analysis.

\section{Topic 2: the relevance of practicum}

The five teachers who had the opportunity to apply this method in their practicum, refer to it as fundamental for their pedagogical preparation. Glória acknowledges that she learned a lot from the internships: "Obviously I still have a lot to learn, being in the first year as a full teacher, but [the experience in the internships] helped me a lot in order to apply this method". Filipa reinforces that "we had experiences that triggered in us practices that foment project work, autonomous work, cooperative work; all of those methods that leads to meaningful learning and that allow us to have a much more focused and learner-centred practice".

However, not all participants had the opportunity to apply PjBL in their practicum, being obliged to follow the Cooperating Teacher's methods. Carla states that she learned about this method in ITE, but "in the internships I did it was not the methods that were applied in the class... As I did not experience it in the internship, [when I started my career] I didn't have much experience". And regarding her internships, Bruna says: "I had to follow the Cooperating Teacher's 
methods, where everything was very standard, after page 12 comes page $13 \ldots$ the traditional teaching way".

Research question 2: What is the role of PjBL in the development of teacher professionality conceptions?

Seven teachers consider that, during ITE, there were no major changes in their conceptions about what it means to be a teacher, despite pointing out some aspects of a teacher's work that they were not aware before, such as pedagogical differentiation, as students do not learn in the same way, having the need to constantly change teaching strategies; the multiplicity of tasks, such as planning, behavioural and emotional management, assessment and involvement of the school community; and the existence of different teaching methods, contrary to what they experienced in their school paths that were marked by a transmissive type of teaching. Only one teacher considers that her perspective on the teaching profession has changed significantly due to the knowledge she has obtained about active teaching methods.

All teachers emphasize the importance and relevance of $\mathrm{PjBL}$ for pupils. Although not being the only method they use in their educational practices, they refer advantages such as pupils involvement and motivation to learn, as the predisposition to learn increases due to the emerged themes being of their own interest; the development of social skills transversal to the entire curriculum, namely cooperation, autonomy and communication, which goes far beyond the learning content; and interdisciplinarity, which makes students learn in an integrated way, by creating a link through a topic and giving meaning to their learning.

Asked directly about the role of PjBL in changing their conceptions about educational practices, all teachers consider that the knowledge and contact with this method changed their conceptions significantly. Two new topics emerged through their testimonies, related to learnercentred practices, and curriculum management and flexibility. Aspects such as the involvement and motivation of students to learn, the development of social skills and the interdisciplinary approach, were also mentioned, intersecting with the topics regarding the importance they confer to this method in student learning.

\section{Topic 3: learner-centred practices}

For five teachers, the contact with $\mathrm{PjBL}$, as an active teaching method centred on the student, was decisive in changing their conceptions about teaching professionality. Having a school path mostly characterized by transmissive teaching, Glória reveals that "I wanted [teaching] to be different and believed it could be so. And when I got to know the method that I practice today, I saw that it was possible". Ivo stresses that the perspective he had about teachers teaching and students learning has changed a lot with this method, referring that "students learn without me being there to teach ... without being there to explain ... They learn by themselves. Sometimes they may be learning it wrong, but that is why we are there for, to manage and mediate that process". In turn, Hélia does not rule out the importance that other innovative pedagogies and methods had for her conceptions change, but reinforces the difference that PjBL caused by realizing the different types of work that students can develop, unlike the type of work she did in her school path:

When we are twelve years in a school [as pupils] experiencing the same things over and over again, we think that that is it, we believe it is like that... I thought that teaching was transmissive, because it was always the way I was taught... [PjBL] is one of the methods that made me change my conceptions... the work that is done with pupils is completely different than being seated listening. 


\title{
Topic 4: curricular management and flexibility
}

Curricular flexibility was also referred as a reason for conceptions changing, as teaching can be guided by objectives related to classroom experiences and issues that may arise, rather than being limited to a pre-defined curriculum. For Bruna, the guidelines for following the manual and a rigid curriculum, which she was forced to do during her practicum, did not make sense to her. When she started teaching and tried to apply different methods, such as PjBL, she felt that other teachers saw disorganization in what she saw as pedagogical:

\begin{abstract}
They considered it all to be very alternative, perhaps very disorganized. They did not understand the point... [Project work] forces us to leave the comfort zone, to let go of the crutch of the manual and the class plan... Because kids themselves and their interventions sail the boat in ways that we didn't initially think of... [Work] takes a life of its own... Perhaps older [teachers] have a harder time adapting to this unpredictability, but $[\mathrm{PjBL}]$ marks us and when we start to adapt to it, it stays with us... Project work changes us little by little.
\end{abstract}

Research question 3: How is the induction phase of beginning elementary school teachers characterized?

These teachers' entry into the profession was considered to be challenging, as there are difficulties in finding jobs and in stabilizing their position in a school that offers them the conditions they aspire. None of the teachers have long-term contracts, existing the possibility of changing schools from one year to the next. However, all of them show satisfaction on the schools they currently teach, although not putting aside the idea of changing.

With all the different experiences these teachers experienced during the first years of teaching service, their induction phase can be characterized by three topics related to the support provided by the ITE institution, the support from the schools they started teaching, and the pressure felt during their integration.

\section{Topic 5: support from the ITE institution}

Regarding their integration into the professional life, none of the teachers felt support from the ITE institution they attended, as an institutional initiative. There was no structured program to support the induction period, nor a group of professors specifically designated to follow the integration of recently graduated teachers.

Despite not feeling supported at an institutional level, seven teachers felt supported by the institution's professors. In fact, for three of the interviewees, it was the professors themselves who contacted them and informed them about work opportunities in certain schools. The remaining teachers report the good relationship they maintained with some professors, whom they feel they can count on when having doubts of a scientific and didactical nature. Filipa enthusiastically reports that she never felt helpless after completing the program, having a group of colleagues and professors with whom she still maintains contact:

When one of us didn't know what to do, when something that goes beyond our comfort zone turned up, we bothered the professors. We sent emails, debated questions... They always supported us. After the program we were always in contact because they always told us that if we needed anything, they were at our disposal. We took advantage of that and never felt helpless.

Elisa reinforces this aspect, although she thinks it depends on a personal initiative, since nothing is formally established. It has to do with her own way of seeing things, seeking help from 
professionals she trusts, but she believes that not everyone has her attitude and, therefore, may not feel so accompanied in the first years of their professional life.

\section{Topic 6: support from schools}

Five teachers revealed that they felt some kind of support in the schools where they started teaching, namely by more experienced colleagues and coordinators, whether by showing them what they were doing in their own classroom or by planning some activities together. Filipa reports that she felt immediately integrated, as part of a team, stating that "one of the advantages of this school is the collegiality that was formed between me and the people there... I felt full integration". Glória shares the same feeling, saying that:

The teachers' group where I work is very connected and we are used to work as a team... I am one of the youngest and, when I have doubts, I have someone to turn to and, without any problem, they help me. Sometimes we attend each other's classes, to learn more. When we have doubts about how it can be done, we can learn from those who already know and have more experience. So, the integration was very good and I felt supported.

The teachers that did not feel that kind of support from schools reveal that their integration was very fast, with no preparation time and that they had to understand how the institution worked for themselves. Andreia remembers her first year of teaching service with some discomfort, reporting that:

In the first two weeks I felt very lost because I was called in short notice... I didn't have that time to organize things. I already knew the teaching methods of [name of school], but knowing a method is one thing, knowing the way they work is another. In other words, it was a lot at the same time and I felt a little lost and I didn't have much support initially.

Bruna reveals a similar feeling, at the first school where she worked, not feeling supported due to the school policy:

It was very complicated. There was no concern about integrating teachers. The concern was not the teachers' well-being, it was the contentment of the parents, who are paying. I felt lots of difficulties, the volume of work was always high and very demanding. What we do with pupils is pleasurable, but it gets to a point where our energy is no longer enough for everything.

The pressure felt in her integration, the subject of the next topic, led Bruna to look for another school, in the following year, where she now feels more integrated.

\section{Topic 7: pressure during induction phase}

Six teachers state that they have not felt any pressure to follow the practices of more experienced teachers or of the school itself, as they identify themselves with the curricular models and pedagogical principles of those schools. For these teachers, integrating the teaching staff of these schools allowed them to develop educational practices which they identified themselves with.

The pressure felt by these teachers during induction phase is concerned to aspects related to the way schools are organized and to the school community, namely the children's parents. Carla says that, in the first school she taught, she failed to implement PjBL because "it had a very directed and very tight policy: 'we have to do this because if you don't, you are not welcome in this house'... it had very well-defined rules and I had to follow them". And Filipa recalls the pressure that her pupils' parents exerted in her first year, referring that "it was somehow suffocating... [the parents] were constantly [at school] asking something... If the children could not do homework 
autonomously, they even sent emails late at night complaining". Bruna feels that the difficulties and pressure felt during teachers' integration are mainly due to their inexperience and the fact that her colleagues look at the new teachers as not very competent:

It is difficult, when they see us as kids... [Teachers can use] different strategies, but at the beginning I did not have the ability to confront others and defend my ideas. I got to a point where I felt I was jeopardizing children's learning just so I wouldn't feel that pressure... [The observations] of colleagues become uncomfortable and we give in to that pressure a little bit. And when we realize, we are not teaching the way we like it.

\section{Research question 4: What aspects facilitate and/or hinder teachers' PD at the beginning of their careers?}

All teachers identified opportunities and difficulties for their PD in the schools they are teaching. The mentioned aspects diverge from sharing practices among colleagues, to difficulties in investing in their own training due to the amount of work they have. In some cases, school's own policies are also considered a challenging factor for their PD. Thus, three topics of analysis emerged from teachers' reports.

\section{Topic 8: sharing experiences}

Four teachers refer to sharing experiences and joint preparation of activities as opportunities for their PD. Glória says that she has several meetings with teachers from different curricular areas throughout the year, which allows her to get ideas for activities within the scope of projects that she is developing with her pupils. And Ivo values regular contact with colleagues, in which strategies and resources are shared. Filipa also mentions the enormous learning opportunity she had with the exchange of experiences with older colleagues, as she "managed to mobilize some activities that favoured cooperative and autonomous work and they also had an openness for this type of initiatives... No doubt it was an opportunity for my PD".

\section{Topic 9: in-service teacher education}

The need for more training after ITE was mentioned by four teachers. However, the high volume of work, the consequent shortness of time and the lack of training offers from the school they teach, was referred to as a hindrance. In spite of wanting to invest more in her training, Carla says that the school only offers one or two short training sessions per year, which is not enough for her own needs. The challenges of the first years of professional activity causes Elisa to feel some difficulties in investing in her training: "Sometimes it becomes a little challenging. I want to learn more, but sometimes work [doesn't allow it]... The balance between professional life, personal life and other things... it's not easy". Glória also demonstrates a willingness to continue her training, despite considering that it is impossible at the present moment:

I would like to have more time to invest in my training and time is, at this moment, what I don't have. I feel very overloaded with work, managing all that we have to do, the materials [that we have to create]... Basically, I would like to have more time and be able to invest a lot more, to be able to read, to investigate about what I would like to improve, because now I begin to see some weaknesses that I would like to fix.

\section{Topic 10: school policy}

Institutional demands are factors that, from the perspective of four teachers, influence their PD negatively. Filipa speaks of the broad agenda of activities created by the school, which requires time and dedication, taking some time from other planned activities. Andreia confesses that the 
excess of reports, bureaucracy and school management control, limits her time to plan different activities within the scope of projects. Bruna's speech demonstrates her disagreement with general educational policies, as they limit teachers' curriculum management and pedagogical differentiation, due to all the inherent demands:

I feel that teaching is like filling children with content... We cannot continue to clog them with things to learn. Nor to force them to do the same thing at the same time, and to have the same exams for everyone. Where is the flexibility, adaptability and individualized work, when the exam comes and everything is the same for everyone, even knowing that some will not be able to do it? It is impossible to do project work if we have a template to apply to all classes and all students. We need to have the courage to say "it can't be like this".

The scheme presented in figure 1 systematizes the relations between the discussed topics, showing how elementary school beginning teachers perceive the role of PjBL in their PD.

Figure 1. The role of PjBL in the PD of elementary school teachers at the beginning of their careers.

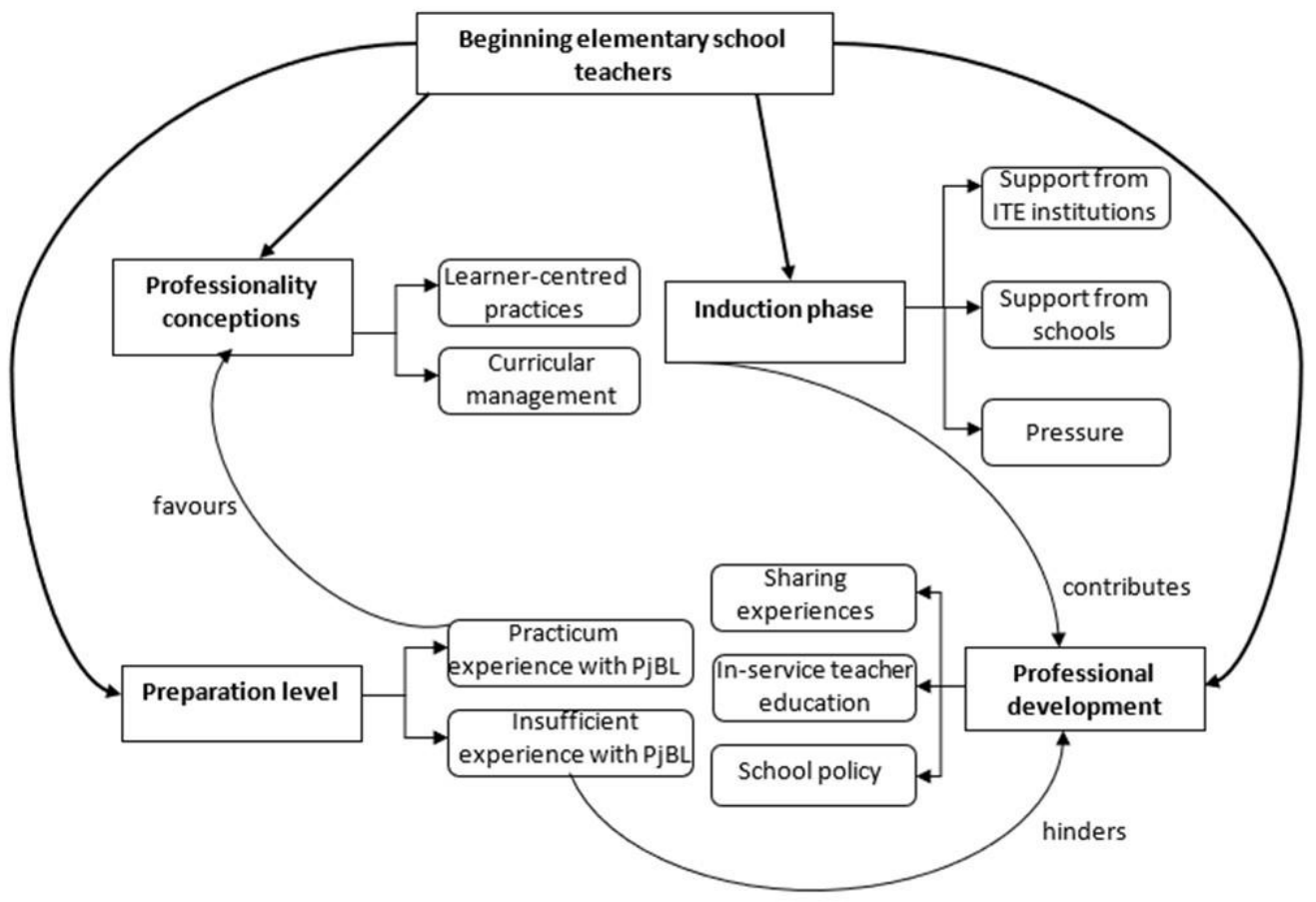

\section{DISCUSSION AND CONCLUSION}

The collected testimonies allow us to verify that all participants in this research value and care about their PD and view the knowledge and practice of PjBL as fundamental elements in the construction of their professional identity and teaching conceptions.

During ITE, teachers had contact with PjBL at a theoretical, didactical and practical level, as suggested by T. Leite and Arez (2011), although it does not seem to have been enough to fully prepare them to apply this method in their educational practices. This fact may be associated with the fragmented structure of the programs' curriculum and insufficient articulation between theory and practice, as suggested by Gatti and Nunes (2009). Despite providing them with the necessary bases for educational practices, ITE does not seem to adequately prepare them for the application of more demanding methods, in the first years of their teaching career (Harju \& Niemi, 2016). There is a need to continue to invest in the inclusion of active teaching methods in ITE (Mielkov et al., 2021), given that their school path is marked by a mostly transmissive learning model. For these teachers, the practicum seems to represent a privileged moments for the application of active teaching methods. However, due to the school contexts in which future teachers are integrated, 
this approach is often not possible and not everyone is able to have this experience. It is necessary to promote a closer connection between ITE institutions and internships schools, as well as to offer in-service training to Cooperating Teachers, so that they'll be able to work together with the common objective of improving the teaching quality of the elementary school levels.

$\mathrm{PjBL}$ advantages promote conception changes in educational practices and professionality. Teachers recognize that the knowledge they acquired about this method has brought them a different perspective on the teaching-learning process, in which the teacher ceases to be the centre, moving from a more transmissive teaching perspective to a more active one (Choi et al., 2019). The possibilities that PjBL open up in terms of curriculum management and flexibility, changes teachers' perspective of the curriculum itself and the way it can be applied. Despite being a challenge for them (Revelle, 2019), it is also a cause for conceptions change about professionality. It is important to reinforce the practicum in ITE, promoting teaching experiences based on PjBL, so that teachers will be able to start viewing their profession differently, sooner. The potential of this method for children's learning and the competences it develops, should be verified earlier by teachers. In this way, ITE have an additional responsibility in promoting that knowledge, since it is during its programs that many future teachers have their first contact with project work.

Being considered a demanding phase (Harju \& Niemi, 2016), the induction period of these teachers is marked by a lack of support from ITE institutions. However, teachers who have kept in touch with their professors, highly value their help. In order that all beginning teachers could have the same kind of follow up, we consider relevant to create induction programs or the figure of a mentor (Bezzina, 2006; OECD, 2011; Rudkevych et al., 2020) that establish a connection between the end of the program and the beginning of the profession. We consider that the joint work between universities and schools is extremely important, not only in the practicum period, but also in the professional integration phase. Additionally, teachers value the support of more experienced teachers and colleagues, being aspects that facilitate their entry into the profession (Bezzina, 2006), since the pressure felt in some school contexts, related to excessive formalities, can be a limiting factor in the development of innovative educational practices and teacher integration.

In terms of their PD, we verified a complementarity between three dimensions (Ilaiyan \& Safadi, 2016; Oliveira-Formosinho, 2009; Vonk, 1995). On a personal understanding dimension, the results show that teachers are concerned with their individual growth and professional identity, by developing their own ideas about good teaching practices. In this sense, the sense of community and sharing among colleagues, felt by some teachers, is a significant contribution. There is also a concern on a knowledge and skills dimension, in which teachers reveal they want to know more in terms of scientific and pedagogical knowledge and to develop organizational skills for the teachinglearning process, being willing to invest in their in-service training. There is also a focus on an ecological dimension through the effort to integrate the school environment, which is not an easy task due to school policies that require time and dedication to adapt, making it difficult to invest in more demanding teaching methods, such as PjBL. During these teachers' induction phase, PjBL's role in their PD is transversal to all these dimensions, as they seek to build their professional identity through good teaching practices, develop their pedagogical skills in terms of active teaching methods, adapting to the school environment by introducing innovations and trying to make a difference in the school community.

There are some limitations to this research due to, above all, the current pandemic situation that the country was going through and its consequent restrictions, which is important to acknowledge. In order to complement the interviews, it was planned to carry out observations of teachers' project work sessions, but the limitations of presence of external elements at the school grounds prevented this kind of data collection. Observation would have been useful to draw conclusions about the actual way in which beginner teachers apply this method in their classrooms and how it influences their PD throughout their induction period. Another factor that can be 
considered as a limitation of this research is related to the interview open nature questions which, while giving the participants an opportunity to express themselves freely about their experiences, does not focus on specific questions or particular situations that we would have liked to obtain more knowledge.

There is still a way to go in optimizing the approach of active teaching methods in ITE, since beginning teachers show some difficulties in integrating these methods in their teaching practices. We believe that there are two fundamental agents that can promote or hinder beginning teachers' PD: ITE institutions and schools. Both have the responsibility and the duty to promote the quality of education by adopting measures that would give assets for beginning teachers' PD. While ITE institutions could offer more training options and support in the first years of service, schools could promote collaborative work groups or show more flexibility so that beginning teachers could attend trainings of their choices. In order to facilitate the integration of beginning teachers, we are convinced that ITE institutions could start to follow the example of some countries that have implemented the University Schools system (Gerholz et al., 2020; Smith, 2016), maintaining a constant connection with schools and establishing a continuity between ITE and the induction phase, so that beginning teachers won't feel an abyss when they finish the program and start their professional life.

We also consider relevant to encourage using PjBL during the induction phase, given its potential to transform teachers' identity and their PD, for the rest of their career. Insufficient preparation by ITE associated with integration difficulties and overwork in the first years of their careers, can lead teachers to abandon more demanding methods (Tickle, 2000). Based on the assumption that the induction period is central to the construction of professional identity (Flores \& Day, 2006; Tickle, 2000), being even more decisive than ITE, this PD phase is a crucial moment for the use of PjBL, given the relevance that we recognize for students' learning and the intention that it becomes a present strategy in the educational practices' repertoire of beginning teachers during the rest of their careers.

Future investigations could involve identifying beginning teachers' needs, seeking to understand which kind of knowledge is relevant to teaching and to their PD and how this knowledge is acquired. The focus of this research could also be extended to other ITE institutions and schools, identifying institutional strategies for beginning teachers' integration and good practices in promoting favourable conditions for their PD. Studies of this nature could open perspectives for the training needs of elementary school teachers, so that ITE institutions and schools could respond to and for creating effective models of integration and PD, based on the identified good practices.

Authors' Contributions: Tempera, T.: conception and design, acquisition of data, analysis and interpretation of data, drafting the article, critical review of important intellectual content; Tinoca, L.: conception and design, acquisition of data, analysis and interpretation of data, drafting the article, critical review of important intellectual content. All authors have read and approved the final version of the manuscript.

Ethics Approval: Not applicable.

Acknowledgments: The authors would like to thank the funding for the realization of this study provided by FCT (Fundação para a Ciência e a Tecnologia - Portugal), Finance Code SFRH/BD/137693/2018.

\section{REFERENCES}

Amado, J. (2017). Manual de investigação qualitativa em educação (3a ed). Coimbra: Imprensa da Universidade de Coimbra. https://doi.org/10.14195/978-989-26-0879-2

Bezzina, C. (2006). Views from the trenches: Beginning teachers' perceptions about their professional development. Journal of In-Service Education, 32(4), 411-430. https://doi.org/10.1080/13674580601024515 
Choi, J., Lee, J. H., \& Kim, B. (2019). How does learner-centered education affect teacher self-efficacy? The case of project-based learning in Korea. Teaching and Teacher Education, 85, 45-57.

https://doi.org/10.1016/i.tate.2019.05.005

Cohen, L., Manion, L., \& Morrison, K. (2018). Research methods in education (8th ed). Routledge Falmer.

Condliffe, B., Quint, J., Visher, M. G., Bangser, M. R., Drohojowska, S., Saco, L., \& Nelson, E. (2017). Project-Based Learning: A Literature Review (Unpublished Working Paper). https://s3-us-west-

1.amazonaws.com/ler/MDRC+PBL+Literature+Review.pdf

Diesel, D., \& Matos, J. F. (2019). Espaços educativos inovadores e o olhar dos professores para a ação docente. Educação e Cultura Contemporânea, 16(43), 375-395. https://doi.org/10.5935/2238-1279.20190018

Flores, M. A., \& Day, C. (2006). Contexts which shape and reshape new teachers' identities: A multi-perspective study. Teaching and Teacher Education, 22(2), 219-232. https://doi.org/10.1016/i.tate.2005.09.002

Gatti, B. A., \& Nunes, M. M. R. (Orgs). (2009). Formação de professores para o Ensino Fundamental: estudo de currículos das licenciaturas em Pedadogia, Língua Portuguesa, Matemática e Ciências Biológicas. FCC-DPE (Coleção Textos FCC, vol. 29). http://www.fcc.org.br/pesquisa/publicacoes/textos fcc/arquivos/1463/arquivoAnexado.pdf

Gerholz, K., Neubauer, J., Reinke, H., Wagner, A., Lazarová, B., Pol, M., Bader, C., Marko, N., Wilbers, K., Midjo, B. I., Stenoien, I., Smith, K., Sobral, C., Tinoca, L., \& Tempera, T. (2020). Institutional description of University School Concepts in Europe - Intelectual output 1 in the EdUSchool Project. https://www.university-schools.eu/projectoutputs/

Harju, V., \& Niemi, H. (2016). Newly Qualified Teachers' Needs of Support for Professional Competences in Four European Countries: Finland, the United Kingdom, Portugal, and Belgium. Center for Educational Policy Studies Journal, 6(3), 77-100. https://doi.org/10.26529/cepsj.66

Haug, B. S., \& Mork, S. M. (2021). Taking 21st century skills from vision to classroom: What teachers highlight as supportive professional development in the light of new demands from educational reforms. Teaching and Teacher Education, 100, 103286. https://doi.org/10.1016/j.tate.2021.103286

Ilaiyan, S., \& Safadi, R. (2016). Characteristics of “Exemplary Teachers" and Possible Factors Affecting Their Realization According to the Perception of Principals from the Arab Sector in Israel. Creative Education, 07(01), 114-130. https://doi.org/10.4236/ce.2016.71012

Leite, T. (2018). O ensino das áreas curriculares no 1.o Ciclo do Ensino Básico. In F. Veiga (Ed.), O Ensino na Escola de Hoje (pp. 127-159). Lisboa: Climepsi Editores.

Leite, T., \& Arez, A. (2011). A Formação através de Projetos na Iniciação à Prática Profissional. Da Investigação Às Práticas, 1(3), 79-99. http://hdl.handle.net/10400.21/1684

Mason, J. (2017). Qualitative Researching (3rd ed.). Sage Publications.

Mielkov, Y., Bakhov, I., Bilyakovska, O., Kostenko, L., \& Nych, T. (2021). Higher education strategies for the 21st century : philosophical foundations and the humanist approach. Revista Tempos e Espaços Em Educação, 14(33), e15524. https://doi.org/http://dx.doi.org/10.20952/revtee.v14i33.15524

OECD [Organisation for Economic Co-operation and Development]. (2011). Teachers Matter: Attracting, Developing and Retaining Effective Teachers. https://doi.org/10.1787/9789638739940-hu

Oliveira-Formosinho, J. (2009). Desenvolvimento profissional dos professores. In J. Formosinho (Ed.), Formação de professores - Aprendizagem profissional e acção docente (pp. 221-284). Porto: Porto Editora.

Onyshkiv, Z., Kodliuk, Y., Lesina, T., Malyna, O., \& Kichuk, N. (2021). Areas of modernization of preparation of future elementary school teachers in the countries of the European community. Revista Tempos e Espaços Em Educação, 14(33), e15615. https://doi.org/http://dx.doi.org/10.20952/revtee.v14i33.15615

Príncepe, L., \& André, M. (2019). Condições de trabalho na fase de indução profissional dos professores. Curriculo Sem Fronteiras, 19(1), 60-80. https://www.researchgate.net/publication/346965927

Revelle, K. Z. (2019). Teacher perceptions of a project-based approach to social studies and literacy instruction. Teaching and Teacher Education, 84, 95-105. https://doi.org/10.1016/j.tate.2019.04.016

Rudkevych, N., Hotsuliak, K., Marynchenko, H., Hryashchevskaya, L., \& Ivanova, T. (2020). The development of teachers' professional competence within the conditions of modernization of the educational environment. Revista Tempos e Espaços Em Educação, 13(32), e14728. https://doi.org/10.20952/revtee.v13i32.14728 
Smith, K. (2016). Partnerships in teacher education - Going beyond the rhetoric, with reference to the Norwegian context. CEPS Journal - Center for Educational Policy Studies Journal, 6(3), 17-36. https://doi.org/10.26529/cepsj.63

Spooner-Lane, R. (2016). Mentoring beginning teachers in primary schools: research review. Professional Development in Education, 43(2), 253-273. https://doi.org/10.1080/19415257.2016.1148624

Tamim, S. R., \& Grant, M. M. (2013). Definitions and Uses: Case Study of Teachers Implementing Project-based Learning. Interdisciplinary Journal of Problem-Based Learning, 7(2), 5-16. https://doi.org/10.7771/1541-5015.1323

Tempera, T., \& Tinoca, L. (2020). Contributions of Project-Based Learning in Initial Teacher Education for Elementary School Teachers. Comunicação Apresentada Ao EDiTE Conference 2020 - International Diversity in Teacher and Higher Education Research in the 21st Century Conference. http://edite-events.elte.hu/

Tickle, L. (2000). Teacher induction: The way ahead. Philadelphia: Open University Press.

Vonk, J. H. (1995). Conceptualizing Novice Teachers' Professional Development: A Base for Supervisory Interventions. Annual Meeting of the American Educational Research Association, April, San Francisco, 1-13.

https://eric.ed.gov/?id=ED390838

Received: 31 September 2021 | Accepted: 12 December 2021 | Published: 14 January 2022

This is an Open Access article distributed under the terms of the Creative Commons Attribution License, which permits unrestricted use, distribution, and reproduction in any medium, provided the original work is properly cited. 